Article

\title{
Synthesis, Structures and Luminescence Properties of Metal-Organic Frameworks Based on Lithium-Lanthanide and Terephthalate
}

\author{
Mohammed S. M. Abdelbaky ${ }^{1}$, Zakariae Amghouz ${ }^{1,2, *}$, Santiago García-Granda ${ }^{1}$ and \\ José R. García ${ }^{1}$ \\ 1 Departamentos de Química Física y Analítica y Química Orgánica e Inorgánica, \\ Universidad de Oviedo-CINN, 33006 Oviedo, Spain; saidmohammed.uo@uniovi.es (M.S.M.A.); \\ sgg@uniovi.es (S.G.-G.); jrgm@uniovi.es (J.R.G.) \\ 2 Servicios Científico-Técnicos, Universidad de Oviedo-CINN, 33006 Oviedo, Spain \\ * Correspondence: amghouz.uo@uniovi.es; Tel.: +34-985-103-000 (ext. 5456) \\ Academic Editor: Félix Zamora \\ Received: 13 February 2016; Accepted: 10 March 2016; Published: 16 March 2016
}

\begin{abstract}
Metal-organic frameworks assembled from $\mathrm{Ln}(\mathrm{III}), \mathrm{Li}(\mathrm{I})$ and rigid dicarboxylate ligand, formulated as $\left[\mathrm{LiLn}(\mathrm{BDC})_{2}\left(\mathrm{H}_{2} \mathrm{O}\right) \cdot 2\left(\mathrm{H}_{2} \mathrm{O}\right)\right](\mathbf{M S 1}-6,7 \mathbf{a})$ and $\left[\mathrm{LiTb}(\mathrm{BDC})_{2}\right](\mathbf{M S 7 b})(\mathrm{Ln}=\mathrm{Tb}, \mathrm{Dy}, \mathrm{Ho}$, $\mathrm{Er}, \mathrm{Yb}, \mathrm{Y}_{0.96} \mathrm{Eu}_{0.04}, \mathrm{Y}_{0.93} \mathrm{~Tb}_{0.07}$, and $\mathrm{H}_{2} \mathrm{BDC}=$ terephthalic acid), were obtained under hydrothermal conditions. The isostructural MS1-6 crystallize in monoclinic $P 2{ }_{1} / \mathrm{c}$ space group. While, in the case of $\mathrm{Tb}^{3+}$ a mixture of at least two phases was obtained, the former one (MS7a) and a new monoclinic C2/c phase (MS7b). All compounds have been studied by single-crystal and powder $X$-ray diffraction, thermal analyses (TGA), vibrational spectroscopy (FTIR), and scanning electron microscopy (SEM-EDX). The structures of MS1-6 and MS7a are built up of inorganic-organic hybrid chains. These chains constructed from unusual four-membered rings, are formed by edge- and vertex-shared $\left\{\mathrm{LnO}_{8}\right\}$ and $\left\{\mathrm{LiO}_{4}\right\}$ polyhedra through oxygen atoms O3 (vertex) and O6-O7 (edge). Each chain is cross-linked to six neighboring chains through six terephthalate bridges. While, the structure of $\mathbf{M S 7 \mathbf { b }}$ is constructed from double inorganic chains, and each chain is, in turn, related symmetrically to the adjacent one through the $c$ glide plane. These chains are formed by infinitely alternating $\left\{\mathrm{LiO}_{4}\right\}$ and $\left\{\mathrm{TbO}_{8}\right\}$ polyhedra through $(\mathrm{O} 2-\mathrm{O} 3)$ edges to create $\mathrm{Tb}-\mathrm{O}-\mathrm{Li}$ connectivity along the $c$-axis. Both MS1-6,7a and MS7b structures possess a 3D framework with 1D trigonal channels running along the $a$ and $c$ axes, containing water molecules and anhydrous, respectively. Topological studies revealed that MS1-6 and MS7a have a new 2-nodal 3,10-c net, while MS7b generates a 3D net with unusual $\beta$-Sn topology. The photoluminescence properties Eu- and Tb-doped compounds (MS5-6) are also investigated, exhibiting strong red and green light emissions, respectively, which are attributed to the efficient energy transfer process from the BDC ligand to $\mathrm{Eu}^{3+}$ and $\mathrm{Tb}^{3+}$.
\end{abstract}

Keywords: lanthanide-organic frameworks; dicarboxylate; hydrothermal; crystal structure; topology; photoluminescence

\section{Introduction}

Metal-organic frameworks (MOFs), as an important class of advanced functional materials, have received extensive attention due to their great potential application in various research areas, such as gas adsorption/storage [1-5], liquid separation [6], drug delivery [4,7], and heterogeneous catalysis [8-10]. Among different classes of MOFs, lanthanide MOFs (LnMOFs) [11-15], which can be synthesized using a wide range of lanthanide cations and organic ligands, have been investigated in the fields of coordination chemistry, inorganic chemistry, and material chemistry, not only for their diverse architectures due to high coordination numbers and large ionic radii of lanthanide cations, but also for 
the potential applications in the field of luminescence [13-21], because of their increased brightness and emission quantum yield [22,23], and also in magnetism [11,24-28]. To obtain functional MOFs, considerable efforts have been made and tremendous progress has been achieved. However, challenges in crystal engineering still remain for controlling the chemical composition and dimensionality. It is well-known that the crystal structure is generally driven by the coordination mode of the metal center, solvent system, temperature, $\mathrm{pH}$, and so on [29-32]. Furthermore, the geometry and nature of the organic ligands play an important role in determining the final structures and topologies [33]. As an important class of organic ligands, those containing the carboxyl groups that have been applied in the preparation of LnMOFs due to the affinity of lanthanides cations to carboxylate oxygen atoms. In particular, we focused our research on the dianion organic linker 1,4-benzenedicarboxylic acid (BDC), due to its structural rigidity, a diversity of coordination geometries, and the possibility to facilitate the formation of structures with large voids [34,35]. Alkali-based MOFs [36] are not extensively explored, in comparison with transition metals or lanthanide-based MOFs, despite the incorporation of alkali cations into MOFs being an interesting development of MOF chemistry, through exploitation of their various coordination modes, low polarizability, and unique affinity for basic molecules $[37,38]$. Among these compounds, the lithium-based MOFs [39-46] are attracting particular interest due to recent experimental and theoretical studies showing enhanced $\mathrm{H}_{2}$ uptake in lithium doped MOFs [47-54]. Moreover, they are promising candidates for replacing the conventional electrode in Li-ion batteries, exhibiting a high reversible specific capacity and excellent cyclability [55-58]. Many studies have been carried out using the hydrothermal route to prepare Ln-BDC [20,59-61] or alkali-BDC [62-65] based frameworks, while the first example of MOFs assembled from Li-Ln-BDC has been recently reported by us [12].

Inspired by this previous work and in continuation of our ongoing studies on the design of novel alkali-lanthanide hetero-MOFs, herein we report the full structural characterization of novel lithium-lanthanide-containing MOFs, formulated as $\left[\operatorname{LiLn}(\mathrm{BDC})_{2}\left(\mathrm{H}_{2} \mathrm{O}\right) \cdot 2\left(\mathrm{H}_{2} \mathrm{O}\right)\right](\mathrm{Ln}=\mathrm{Dy}(\mathbf{M S 1})$, Ho (MS2), $\mathrm{Er}$ (MS3), $\mathrm{Yb}$ (MS4), $\mathrm{Y}_{0.96} \mathrm{Eu}_{0.04}$ (MS5), and $\mathrm{Y}_{0.93} \mathrm{~Tb}_{0.07}$ (MS6)) and [LiTb(BDC) 2 ] (MS7b). Their luminescence properties have been investigated.

\section{Experimental Section}

\subsection{Hydrothermal Synthesis}

[LiLn $\left.(\mathrm{BDC})_{2}\left(\mathrm{H}_{2} \mathrm{O}\right)\right] \cdot 2\left(\mathrm{H}_{2} \mathrm{O}\right)$ (MS1-4 and MS7) were synthesized under hydrothermal conditions. In a typical synthesis, $0.08 \mathrm{~g}(0.5 \mathrm{mmol})$ of terephthalic acid $\left(\mathrm{H}_{2} \mathrm{BDC}\right), 0.14 \mathrm{~g}(3.5 \mathrm{mmol})$ of $\mathrm{LiOH} \cdot \mathrm{H}_{2} \mathrm{O}$, and $(1 \mathrm{mmol})$ of $\mathrm{LnCl}_{3} \cdot 6 \mathrm{H}_{2} \mathrm{O}$ (Tb: $37 \mathrm{~g}$; Dy: $0.38 \mathrm{~g}$; Ho: $0.38 \mathrm{~g}$; Er: $0.38 \mathrm{~g}$; Yb: $0.39 \mathrm{~g}$ ) were dissolved in a mixture of distilled water $(5 \mathrm{~mL})$ and ethanol $(5 \mathrm{~mL}) \cdot\left[\mathrm{Eu}_{0.04} \mathrm{Y}_{0.96}(\mathrm{BDC})_{2}\left(\mathrm{H}_{2} \mathrm{O}\right)\right] \cdot 2 \mathrm{H}_{2} \mathrm{O}$ (MS5) and $\left[\mathrm{Tb}_{0.07} \mathrm{Y}_{0.93}(\mathrm{BDC})_{2}\left(\mathrm{H}_{2} \mathrm{O}\right)\right] \cdot 2 \mathrm{H}_{2} \mathrm{O}$ (MS6) have been obtained following the same procedures as described above, by using solutions of $\mathrm{Y}: \mathrm{Ln}$ with a molar ratio of 19:1 previously prepared by dissolving: $0.29 \mathrm{~g}$ $(0.95 \mathrm{mmol})$ of $\mathrm{YCl}_{3} \cdot 6 \mathrm{H}_{2} \mathrm{O}$ and $0.03 \mathrm{~g}(0.05 \mathrm{mmol})$ of $\mathrm{EuCl}_{3} \cdot 6 \mathrm{H}_{2} \mathrm{O}$ or $\mathrm{TbCl}_{3} \cdot 6 \mathrm{H}_{2} \mathrm{O}$ for MS5 and MS6, respectively, in a mixture of ethanol $(5 \mathrm{~mL})$ and distilled water $(5 \mathrm{~mL})$. The both solutions have been stirred for $24 \mathrm{~h}$. The synthesis of all compounds has been done in presence of tartaric acid and an amount of $1 \mathrm{mmol}(0.21 \mathrm{~g})$ was necessary to obtain these compounds. In all cases the reaction mixture was stirred at room temperature to homogeneity and then placed in a Teflon-lined stainless vessel $(40 \mathrm{~mL})$ and heated to $180{ }^{\circ} \mathrm{C}$ for three days under autogenous pressure and, afterwards, cooled to room temperature. The resulting products were filtered off, washed thoroughly with distilled water, and finally air-dried at room temperature. Yield: $27 \mathrm{mg}, c a .12 \%$ for all compounds based on Ln. A crystalline phase of parallelepiped-like single-crystals and microcrystalline powder was obtained in the case of MS1-6 while, for MS7, a mixture of plate- and parallelepiped-like crystals and a microcrystalline powder was obtained. 


\subsection{Single-Crystal X-Ray Diffraction Studies}

Collection was performed at $293 \mathrm{~K}$ on an Agilent Gemini CCD diffractometer (Oxford, Oxfordshire, $\mathrm{UK})$, using $\mathrm{CuK} \alpha$ radiation. Images were collected at a $55 \mathrm{~mm}$ fixed crystal-detector distance, using the oscillation method, with $1^{\circ}$ oscillation and variable exposure time per image. The crystal structure was solved by direct methods. The refinement was performed using full-matrix least squares on $\mathrm{F}^{2}$. All non-H atoms were anisotropically refined. All $\mathrm{H}$ atoms were either geometrically placed riding on their parent atoms or located from the difference Fourier map, with isotropic displacement parameters set to 1.2 times the Ueq of the atoms to which they are attached. Crystallographic calculations were carried out using the following programs: CrysAlis CCD [66] for data collection; CrysAlis RED [67] for cell refinement, data reduction and empirical absorption correction; SHELXS-97 [68] for structure solution; XABS2 [69] for refined absorption correction; SHELXL-97 for structure refinement and prepare materials for publication; PLATON [70,71] for the geometrical calculations; and Diamoned [72] for molecular graphics.

\subsection{Powder X-Ray Diffraction Studies}

Powder X-ray diffraction patterns were recorded on X'pert Philips diffractometer with CuK $\alpha$ radiation. The samples were gently ground in an agate mortar in order to minimize the preferred orientation. All data were collected at room temperature over the angular $2 \theta$ range $4^{\circ}-60^{\circ}$ with a step of $0.01^{\circ}$ and a counting time of $1.5 \mathrm{~s} / \mathrm{step}$. The PXRD patterns of the compounds were compared with the calculated ones, indicating that the products have been successfully obtained as crystalline phase for MS1-6 (Figure 1) and as a crystalline mixture composed of at least two phases for MS7 (Figure 2).

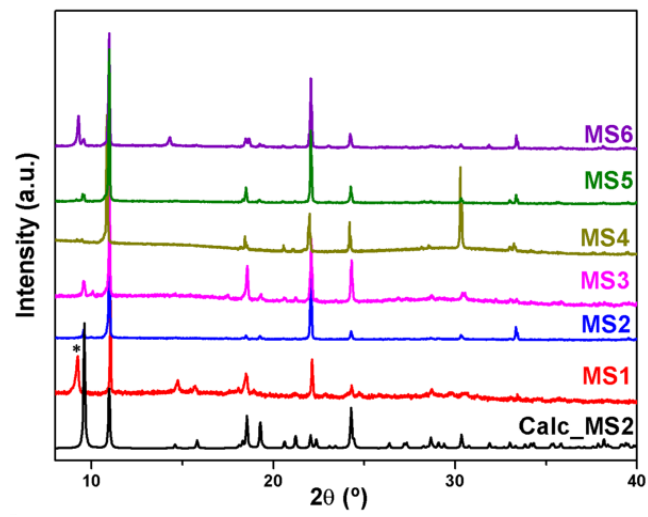

Figure 1. PXRD patterns of MS1-6 compared with the calculated for MS2; ${ }^{*}$ ) shows the peak of an unidentified phase.

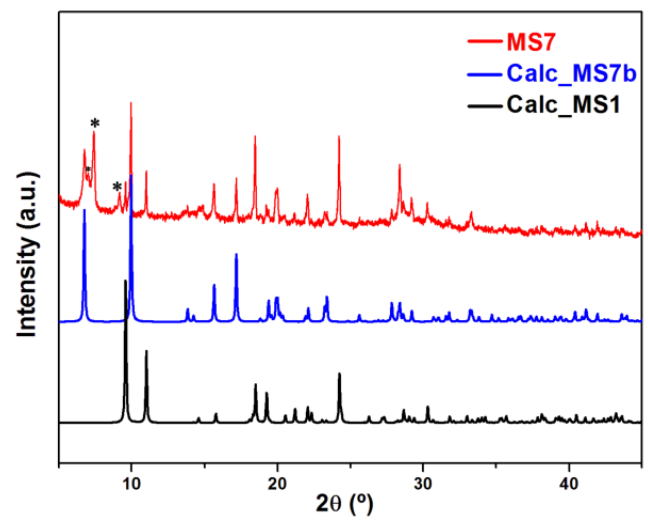

Figure 2. PXRD pattern of MS7, compared with the calculated for MS1 and MS7b; $\left({ }^{*}\right)$ shows the peaks of an unidentified phase. 


\subsection{Morphological Characterization}

SEM micrographs and X-ray microanalysis (SEM/EDX) were recorded by using JEOL-6610LV scanning electron microscope (Akishima, Tokyo, Japan) operating at $30 \mathrm{kV}$ coupled with an Oxford X-Max microanalysis system (EDX). SEM images (Figure S1) show parallelepiped-like morphology and micropowder for MS3 sample, while the plate- and parallelepiped-like morphologies along with micropowder were observed in the case of MS7 sample. EDX provided Y:Eu and Y:Tb quantitative analysis for MS5 and MS6 (Figure S2 and Table S1).

\subsection{Infrared Spectra}

The infrared data were collected at room temperature using a FT-IR Bruker Tensor-27 spectrometer (Billerica, MA, USA) from KBr pellets. The spectra were collected over the range $4000-400 \mathrm{~cm}^{-1}$ by averaging 15 scans at a maximum resolution of $4 \mathrm{~cm}^{-1}$.

\subsection{Thermal Characterization}

A Mettler-Toledo TGA/SDTA851e (Greifensee, Switzerland) was used for the thermal analysis in oxygen dynamic atmosphere $(50 \mathrm{~mL} / \mathrm{min})$ at a heating rate of $10^{\circ} \mathrm{C} / \mathrm{min}$. In this case, $c a .10 \mathrm{mg}$ of powder sample was thermally treated, and blank runs were performed.

\subsection{Photoluminescence Studies}

RT excitation and emission spectra and luminescence lifetimes were measured using a standard spectrofluorometer Edinburgh Instruments FLSP920 (Edimburgh, Scotland, UK), having a 450W Xe lamp as the excitation source. The samples were placed between two quartz plates placed at $45^{\circ}$ from the incident beam and the detector. The luminescence lifetimes sample was excited using a nanopulsed light source at $260 \mathrm{~nm}$. Luminescence decay curves were recorded using a fast-response MCP-PMT detector in cooled housing. Lifetime was estimated by fitting the decay curve with a mathematical model, according to the general formula $I=I_{0} \mathrm{e}^{(-t / t a u)}$ where tau is the lifetime. The optical images of the sample were obtained, upon excitation at 360-370 nm and detecting the emission over $420 \mathrm{~nm}$, by using an automated optical microscope Olympus CAST2 for transmission and fluorescence studies equipped with a motorized stage and a high-resolution digital camera.

\section{Results}

\subsection{Description of the Crystal Structures}

The series of compounds MS1-6 are isoreticular and crystallize in the same monoclinic space group $P 2_{1} / \mathrm{c}$ as revealed by single-crystal X-ray diffraction studies. While the second phase MS7b crystallizes in the monoclinic space group $\mathrm{C} 2 / \mathrm{c}$. The crystallographic and structure refinement data are presented in Table 1, whereas Table S2 shows selected bond angles and lengths for MS1-4 and MS7b compounds. Powder X-ray diffraction measurements (Figure 1), confirm that the series MS1-6 have been successfully obtained as crystalline phases and that the crystals exhibit a strong preferential orientations. However, in case of $\mathrm{Tb}$, the powder X-ray diffraction (Figure 2) indicates that the product of the synthesis consist of at least two identified phases, MS7a which belongs to the series MS1-6 and the second novel phase MS7b. 
Table 1. Crystallographic data for MS1-4 and MS7b.

\begin{tabular}{|c|c|c|c|c|c|}
\hline Identification Code & MS1 & MS2 & MS3 & MS4 & MS7b \\
\hline Empirical formula & $\mathrm{C}_{16} \mathrm{H}_{14} \mathrm{O}_{11} \mathrm{DyLi}$ & $\mathrm{C}_{16} \mathrm{H}_{14} \mathrm{O}_{11} \mathrm{HoLi}$ & $\mathrm{C}_{16} \mathrm{H}_{14} \mathrm{O}_{11} \mathrm{ErLi}$ & $\mathrm{C}_{16} \mathrm{H}_{14} \mathrm{O}_{11} \mathrm{YbLi}$ & $\mathrm{C}_{16} \mathrm{H}_{8} \mathrm{O}_{8} \mathrm{TbLi}$ \\
\hline $\begin{array}{c}\text { Formula } \\
\text { weight/g. } \text { mol }^{-1}\end{array}$ & 551.71 & 554.14 & 556.47 & 562.25 & 494.09 \\
\hline Temperature/K & $293(2)$ & $296(2)$ & $293(2)$ & $293(2)$ & $293(2)$ \\
\hline Wave length & 0.71073 & 0.71073 & 0.71073 & 0.71073 & 0.71073 \\
\hline Crystal system & Monoclinic & Monoclinic & Monoclinic & Monoclinic & Monoclinic \\
\hline \multicolumn{6}{|l|}{ Unit cell dimensions } \\
\hline $\mathrm{a}(\AA)$ & $11.6769(4)$ & $10.1727(7)$ & $10.1678(3)$ & $10.1110(2)$ & 13.611(1) \\
\hline b(Å) & $16.1012(2)$ & $16.1068(8)$ & $16.1139(4)$ & $16.0630(3)$ & $26.1672(5)$ \\
\hline$c(\AA)$ & $13.2509(5)$ & $13.228(1)$ & $13.2366(5)$ & 13.1703(2) & $6.7381(5)$ \\
\hline Calc. density/mg $\cdot \mathrm{m}^{-3}$ & 1.987 & 2.003 & 2.012 & 2.063 & 1.974 \\
\hline $\begin{array}{c}\text { Absorption } \\
\text { coefficient } / \mathrm{mm}^{-1}\end{array}$ & 4.110 & 4.37 & 4.628 & 5.227 & 4.29 \\
\hline$F(000)$ & 1,068 & 1,072 & 1,076 & 1,084 & 944 \\
\hline Crystal size $/ \mathrm{mm}^{3}$ & $0.153 \times 0.084 \times 0.030$ & $0.09 \times 0.08 \times 0.04$ & $0.206 \times 0.157 \times 0.039$ & $0.266 \times 0.083 \times 0.044$ & $0.09 \times 0.08 \times 0.04$ \\
\hline $\begin{array}{l}\text { Theta range for data } \\
\text { collection } /{ }^{\circ}\end{array}$ & 3.27 to 31.81 & 3.28 to 31.16 & 3.27 to 31.26 & 3.29 to 31.39 & 3.3 to 31.4 \\
\hline Index ranges & $\begin{array}{c}-17 \leqslant h \leqslant 17 \\
-23 \leqslant k \leqslant 22 \\
-18 \leqslant l \leqslant 19\end{array}$ & $\begin{array}{l}-13 \leqslant h \leqslant 14 \\
-22 \leqslant k \leqslant 23 \\
-18 \leqslant l \leqslant 19\end{array}$ & $\begin{array}{l}-14 \leqslant h \leqslant 14 \\
-23 \leqslant k \leqslant 23 \\
-18 \leqslant l \leqslant 19\end{array}$ & $\begin{array}{l}-14 \leqslant h \leqslant 14 \\
-23 \leqslant k \leqslant 23 \\
-18 \leqslant l \leqslant 19\end{array}$ & $\begin{array}{c}-19 \leqslant h \leqslant 19 \\
-38 \leqslant k \leqslant 37 \\
-9 \leqslant l \leqslant 9\end{array}$ \\
\hline Reflections collected & 22,135 & 12,103 & 15,702 & 10,974 & 12,022 \\
\hline Refinement method & $\begin{array}{l}\text { Full-matrix least } \\
\text { squares on } F^{2}\end{array}$ & $\begin{array}{c}\text { Full-matrix least } \\
\text { squares on } F^{2}\end{array}$ & $\begin{array}{l}\text { Full-matrix least } \\
\text { squares on } F^{2}\end{array}$ & $\begin{array}{l}\text { Full-matrix least } \\
\text { squares on } F^{2}\end{array}$ & $\begin{array}{l}\text { Full-matrix least } \\
\text { squares on } F^{2}\end{array}$ \\
\hline Data/restraints/parameters & $5,851 / 2 / 286$ & $5,365 / 15 / 280$ & $5,465 / 6 / 286$ & $5,366 / 6 / 280$ & $2,548 / 0 / 119$ \\
\hline Goodness -of -fit on $F^{2}$ & 1.052 & 1.03 & 1.016 & 1.022 & 1.08 \\
\hline $\begin{array}{l}\text { Final } R \text { indices } \\
(I>2 \text { sigma }(I))\end{array}$ & $\begin{array}{c}R 1=0.0288 \\
(w R 2=0.0682)\end{array}$ & $\begin{array}{c}R 1=0.055 \\
(w R 2=0.150)\end{array}$ & $\begin{array}{c}R 1=0.028 \\
(w R 2=0.061)\end{array}$ & $\begin{array}{c}R 1=0.0283 \\
(w R 2=0.057)\end{array}$ & $\begin{array}{c}R 1=0.0343 \\
(w R 2=0.0585)\end{array}$ \\
\hline$R$ indices (all data) & $\begin{aligned} R 1 & =0.053 \\
(w R 2 & =0.0589)\end{aligned}$ & $\begin{array}{c}R 1=0.109 \\
(w R 2=0.236)\end{array}$ & $\begin{array}{c}R 1=0.048 \\
(w R 2=0.072)\end{array}$ & $\begin{aligned} R 1 & =0.061 \\
(w R 2 & =0.0449)\end{aligned}$ & $\begin{array}{c}R 1=0.0436 \\
(w R 2=0.0624)\end{array}$ \\
\hline $\begin{array}{l}\text { Largest diff. peak } \\
\text { and hole/eÅ }\end{array}$ & 0.545 and -1.335 & 2.74 and -3.21 & 0.950 and -1.452 & 0.736 and -0.103 & 1.70 and -1.60 \\
\hline CCDC no. & 1444552 & 1444554 & 1444553 & 1444556 & 1444555 \\
\hline
\end{tabular}

The asymmetric units in case of MS1-6 (Figure S3a), comprises one $\mathrm{Ln}^{3+}$, one $\mathrm{Li}^{+}$, one BDC, two half-BDC, one coordinated water molecule, and two non-coordinated water molecules. The $\mathrm{Ln}^{3+}$ cation is bonded to eight oxygen atoms, all of them coming from six carboxylate groups which belong to four non-equivalent groups. Its coordination geometry may be described as a distorted bicapped trigonal prism (Figure 3a). Out of the four carboxylate groups surrounding $\mathrm{Ln}^{3+}$, which belong to two different carboxylate groups, each of two contribute with one oxygen atom, and the two remaining carboylates act in chelating mode. The eight $\mathrm{Ln}-\mathrm{O}$ bond distances range from 2.212(2) to 2.473(2) $\AA$, and the average value decreases from $2.368 \AA$ (Dy), $2.362 \AA$ (Ho), $2.348 \AA$ (Er), to $2.334 \AA$ ( $\mathrm{Yb})$. Each $\mathrm{Li}^{+}$ion assumes a distorted tetrahedron environment by coordinating to four crystallographically-independent oxygen atoms (Figure $3 b$ ). These oxygen atoms come from three independent carboxylate groups and one of water molecules. The $\mathrm{Li}-\mathrm{O}$ bond distances range from $1.880(2) \AA$ to $2.060(2) \AA$, with the average values of $1.950 \AA$ (Dy), $1.950 \AA$ (Ho), $1.949 \AA$ (Er), and $1.945 \AA(\mathrm{Yb})$, indicating that the environment of $\mathrm{Li}^{+}$is not affected by the type of $\mathrm{Ln}^{3+}$. The 3D structures of MS1-6 series are built up of inorganic-organic 
hybrid chains; , each chain is, in turn, crosslinked to six neighboring chains through six terephthalate bridges. These chains constructed from unusual four-membered rings (Figure 4c) are formed by edge- and vertex-shared $\left\{\mathrm{LnO}_{8}\right\}$ and $\left\{\mathrm{LiO}_{4}\right\}$ polyhedra (Figure $4 \mathrm{a}, \mathrm{b}$ ) through oxygen atoms O6-O7 (edge) and O3(vertex) (Er, for instance). The isolated four-membered rings stacked along the $a$-axis, are bridged via two equivalent carboxylate groups $\mathrm{O} 1-\mathrm{C} 12-\mathrm{O} 5$ forming the above mentioned hybrid chains (Figure 4d). The distance between adjacent Ln-Li cations in the chain has an average value of $3.395 \AA$. The 3D framework with trigonal channels running along the $a$-axis contains the crystallization water molecules (Figure 5a), which are involved in strong hydrogen bonds between each other and with the carboxylate oxygen atoms (Table S3).

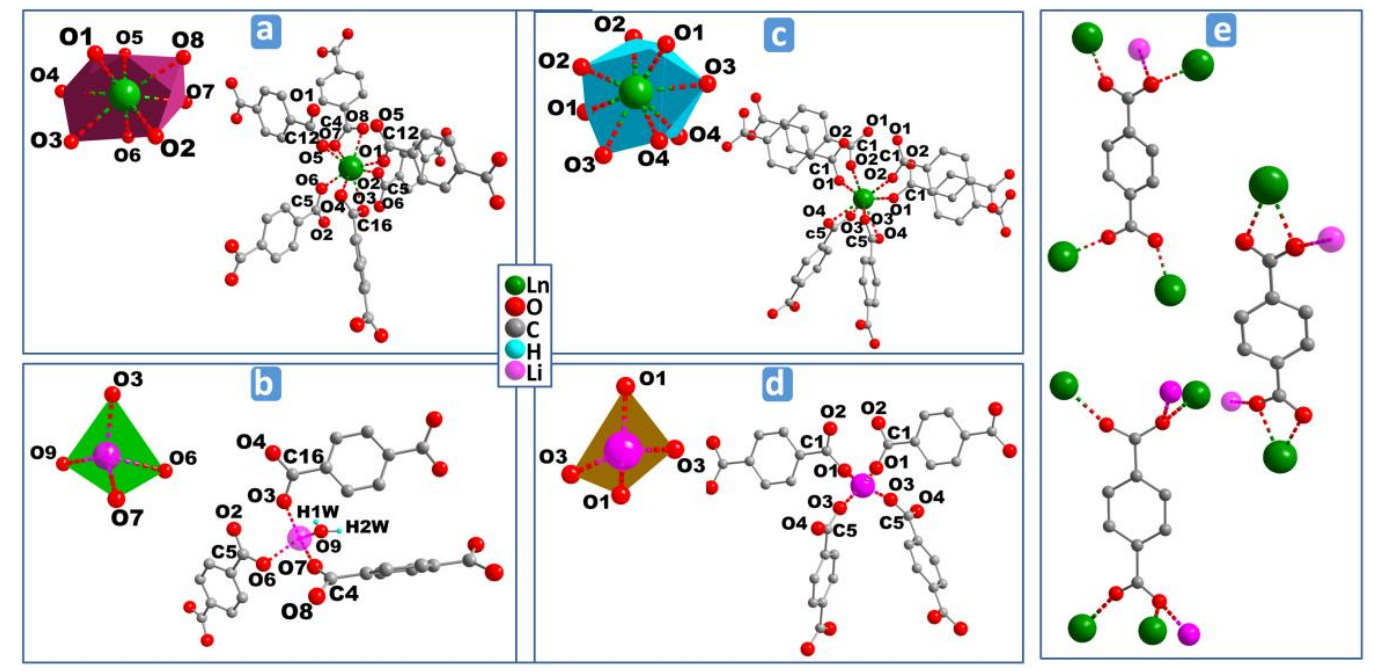

Figure 3. Perspective view of the coordination environments of $\mathrm{Ln}^{3+}$ and $\mathrm{Li}^{+}$cations in $\mathbf{M S 1}-\mathbf{6}(\mathbf{a}, \mathbf{b})$ and MS7b (c,d) and coordination modes of BDC ligand (e).

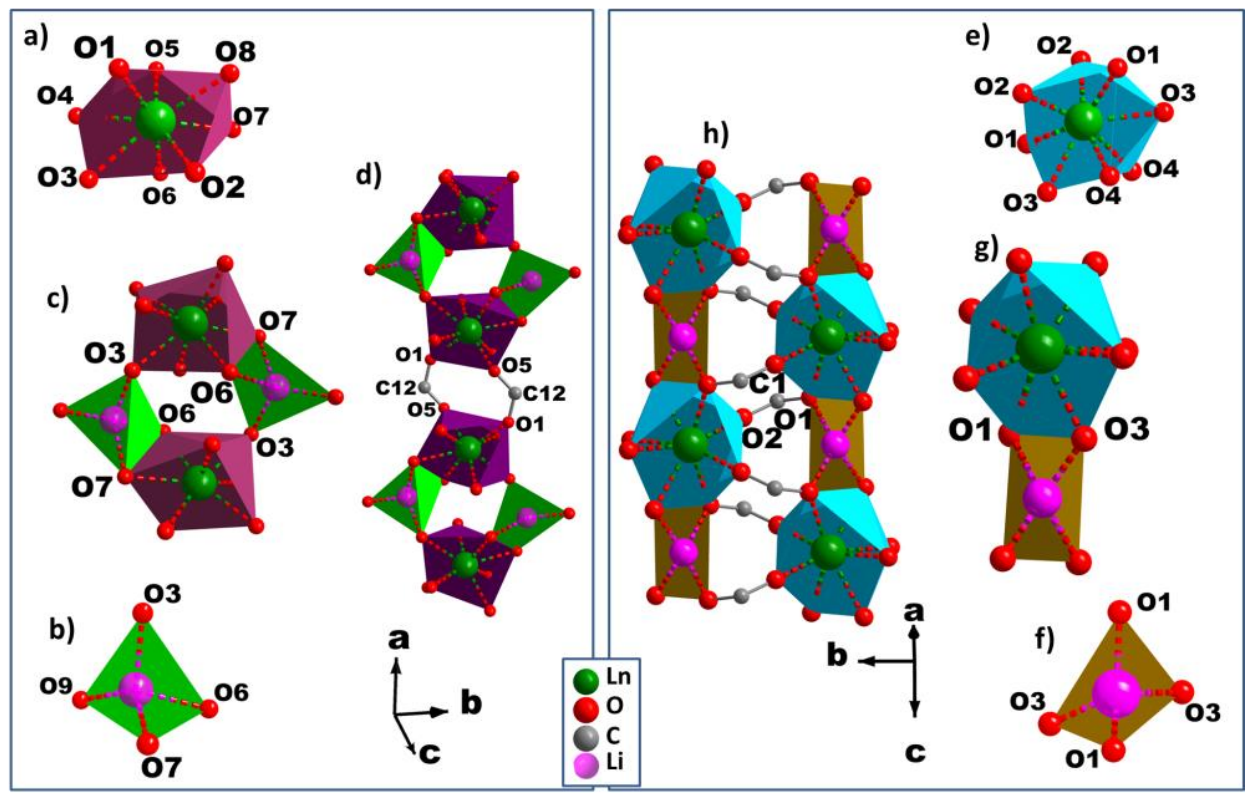

Figure 4. Perspective view of the coordination environments of $\mathrm{Ln}^{3+}$ and $\mathrm{Li}^{+}$cations in $\mathrm{MS1}-6$ (a,b) and MS7b (e,f); the secondary building unit for MS1-6 (c) and MS7b (g), and the infinite chains along the $a$ and $c$ axes for MS1-6 (d) and MS7b (h). 

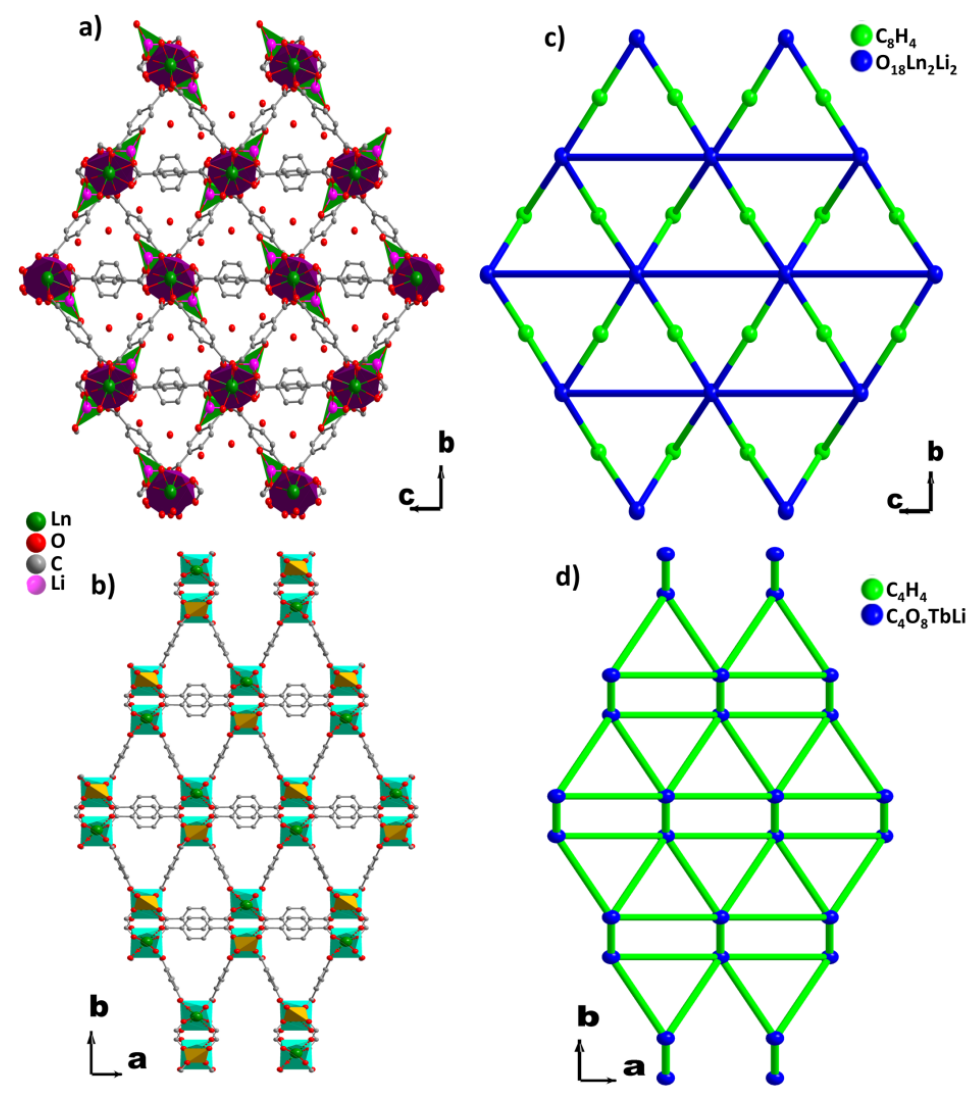

Figure 5. Projection of the structure along the $a$ and $c$ axes for MS1-6 (a) and MS7b (b), respectively. Topological representations of MS1-6 (c) and MS7b (d).

In the case of MS7b, the asymmetric unit (Figure S3b) consists of one $\mathrm{Tb}^{3+}$, one $\mathrm{Li}^{+}$, and two half-BDC. $\mathrm{Tb}^{3+}$ cation shows a distorted square antiprism geometry (Figure 3c) with the average $\mathrm{Tb}-\mathrm{O}$ bond distances of $2.361 \AA$. While $\mathrm{Li}^{+}$cation exhibts a similar distorted tetrahedron coordination polyhedron, like $\mathrm{Li}^{+}$in the series MS1-6. Out of the four carboxylate groups surrounding the $\mathrm{Li}^{+}$ (Figure 3d), which belong to two independent carboxylate groups $\mathrm{O} 1-\mathrm{C} 1-\mathrm{O} 2$ and $\mathrm{O} 3-\mathrm{C} 5-\mathrm{O} 4$, each of two contribute with one oxygen atom $\mathrm{O} 1$ and $\mathrm{O} 3$, where the average $\mathrm{Li}-\mathrm{O}$ bond distances is $1.943 \AA$. The structure of MS7 is constructed from double inorganic chains running along the $c$-axis. Each chain is formed from edge $(\mathrm{O} 2-\mathrm{O} 3)$ shared $\left\{\mathrm{LiO}_{4}\right\}$ and $\left\{\mathrm{TbO}_{8}\right\}$ polyhedra (Figure 4e-g). The $\left\{\mathrm{LiO}_{4}\right\}$ and $\left\{\mathrm{TbO}_{8}\right\}$ polyhedra alternate infinitely in a chain to create $\mathrm{Tb}-\mathrm{O}-\mathrm{Li}$ connectivity along the $c$ direction (Figure 4h), with the Li-Ln distance between adjacent cations in the chain of 3.3765(6) A. Each chain is symmetrically related to the neighbor one through $c$ glide plane. These chains are connected via carboxylate group $\mathrm{O} 1-\mathrm{C} 1-\mathrm{O} 2$ along $c$-axis, forming the inorganic-organic double chains (Figure $4 \mathrm{~h}$ ). These hybrid double chains are, in turn, linked to six neighboring units via six BDC bridges, forming the 3D framework with empty trigonal channels running along the $c$-axis (Figure $5 b$ ).

The coordination modes of BDC anions, found in both MS1-6 and MS7b, are shown in Figure 3e. Each carboxylate group belongs to one of the three modes: (i) groups coordinating one oxygen atom to one $\mathrm{Ln}^{3+}$ cation where the other oxygen is bonded in bridging mode between other $\mathrm{Ln}^{3+}$ and $\mathrm{Li}^{+}$ cations; (ii) groups bridging two adjacent $\mathrm{Ln}^{3+}$ cations; or (iii) bonded to one $\mathrm{Ln}^{3+}$ cation via two oxygen atoms, and in bridging mode between $\mathrm{Ln}^{3+}$ and $\mathrm{Li}^{+}$cations through one of these oxygen atoms. The coordination modes (i) and (iii) have been found in both MS1-6 and MS7b, while mode (ii) has only been found in MS1-6.

The topology of MS1-6 and MS7b have been analyzed with the TOPOS software [73], reducing the structure to a simpler node-and-linker net [74]. The framework of MS1-6 reveals a novel binodal net topology (Figure 5c), simplified as a 2-nodal 3,10-c net with the point symbol of 
$\left\{4.5^{\wedge} 2\right\}-2\left\{4^{\wedge} 14.5^{\wedge} 10.6^{\wedge} 18.7 .8^{\wedge} 2\right\}$. The framework of MS7b exhibits unusual $\beta$-Sn topology with a uninodal 6-connected net with the point symbol of $\left\{4^{\wedge} 8.5^{\wedge} 4.6^{\wedge} 3\right\}$ (Figure $5 \mathrm{~d}$ ).

\subsection{IR Analysis}

The IR spectra of MS1-4 and MS7 are shown in Figure 6. The broad band observed in the $3710-2820 \mathrm{~cm}^{-1}$ region is assigned to $\mathrm{O}-\mathrm{H}$ stretching vibrations of coordinated and uncoordinated water molecules, where in the case of MS7, this band belongs to the hydrated phase MS7a. The characteristic bands for the antisymmetric $v_{\text {asym }(\mathrm{C}=\mathrm{O})}$ and symmetric $v_{\mathrm{sym}(\mathrm{C}=\mathrm{O})}$ vibrations appear at $c a .1589 \mathrm{~cm}^{-1}$ and $1409 \mathrm{~cm}^{-1}$, respectively. The difference between the bands $\left(\Delta v_{\text {asym }}(\mathrm{COO})-\operatorname{sym}(\mathrm{COO})\right.$ $=180 \mathrm{~cm}^{-1}$ ) confirms the bridging mode of the carboxylate groups found in these compounds.

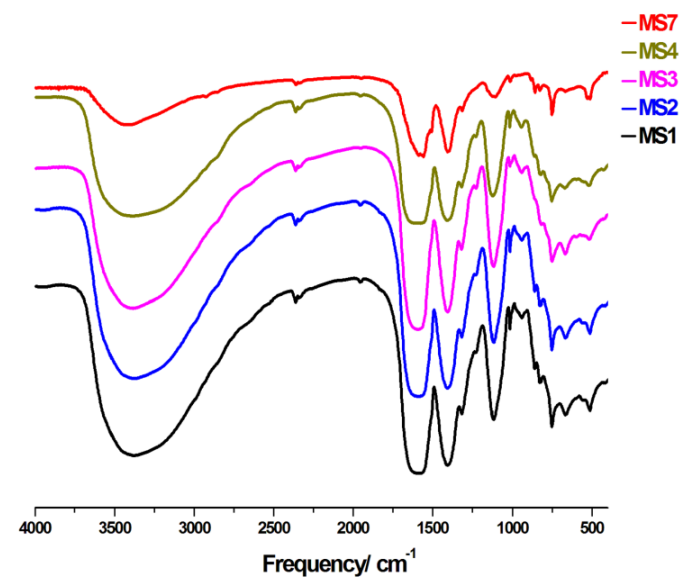

Figure 6. IR spectra of MS1-4 and MS7.

\subsection{Thermal Analysis}

The thermal stability of MS1-6 compounds was investigated by thermogravimetric analysis (TGA/DTG). Figure 7 shows the thermal behavior of MS3 and MS4, while the thermal behavior of MS1, MS2, MS5, and MS6 is shown in Figure S4. All compounds show a similar thermal behavior. The first and second weight loss in the range $25-200{ }^{\circ} \mathrm{C}$ correspond to the loss of the two guest water molecules. The third weight loss between 260 and $330{ }^{\circ} \mathrm{C}$ is attributed to the loss of the coordinated water molecule. The forth weight loss from 330 to $470{ }^{\circ} \mathrm{C}$ corresponds to the beginning of the decomposition of $\mathrm{BDC}$ ligand, while in the fifth step between 480 and $550^{\circ} \mathrm{C}$ the complete oxidation of the BDC is taking place. Further weight loss above $550{ }^{\circ} \mathrm{C}$ is expected to be due to the evacuation of trapped carbonaceous residual species.

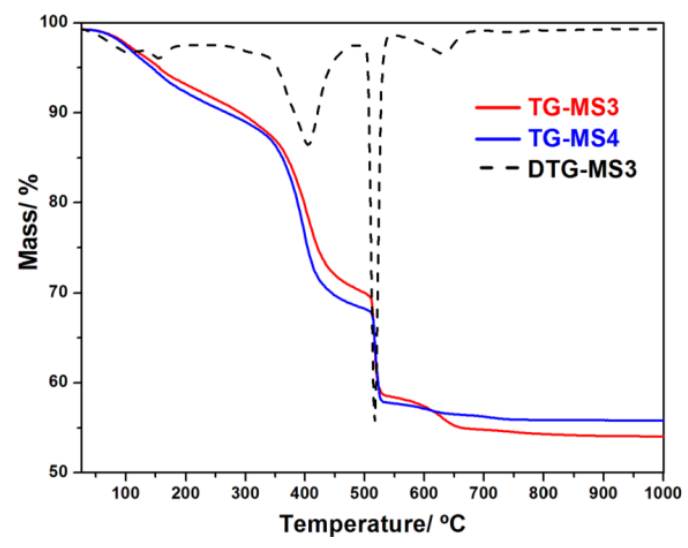

Figure 7. TGA curves of MS3 (Er) and MS4 (Yb). 


\subsection{Potoluminescence Properties}

Taking into account the excellent luminescent properties of $\mathrm{Eu}^{3+}$ and $\mathrm{Tb}^{3+}$ cations, the doped compounds MS5 and MS6 have been prepared as described above. The photoluminescence properties of MS5 and MS6 were investigated at room temperature. The RT luminescence and excitation spectra of MS5 and MS6 are shown in Figure 8. Moreover, selected single-crystals of MS5 and MS6 have been examined by optical microscopy under UV light, and they exhibit strong red and blue-green light emissions, respectively, as illustrated in Figure 9. The both bluish and green light emissions observed in the case of MS6 are related to the variation of $\mathrm{Tb}^{3+}$ content in the crystals, which indicates that the emission could be tuned from green to blue by changing the $\mathrm{Tb}^{3+}$ content. The excitation spectrum of MS5, monitored within the $\mathrm{Eu}^{3+}{ }^{5} \mathrm{D}_{0} \rightarrow{ }^{7} \mathrm{~F}_{2}$ transition, shows a large band with two maxima at $c a$. $275 \mathrm{~nm}$ and $320 \mathrm{~nm}$ are attributed to the excited state of BDC ligand, and also a series of peaks attributed to the electronic transition from the ground states ${ }^{7} \mathrm{~F}_{0,1}$ to the excited states ${ }^{5} \mathrm{D}_{4-1},{ }^{5} \mathrm{G}_{2-6}$, and ${ }^{5} \mathrm{~L}_{6}$ according to the Dieke's diagram [75]. Its emission spectrum, upon excitation at $275 \mathrm{~nm}$, exhibits the characteristic emission lines for $\mathrm{Eu}^{3+}$ cations centered at 580, 590, 615, 651, and $698 \mathrm{~nm}$, which result from deactivation of the ${ }^{5} \mathrm{D}_{0}$ excited state down to the ${ }^{7} \mathrm{~F}_{4-0}$ ground states (Figure $8 \mathrm{~b}$ ). The most intense emission peak, centered at $615 \mathrm{~nm}$ and corresponding to the hypersensitive ${ }^{5} \mathrm{D}_{0} \rightarrow{ }^{7} \mathrm{~F}_{2}$ transition, implies red emission light of $\mathrm{Eu}^{3+}$ with a lifetime $\tau=0.84 \pm 0.01 \mathrm{~ms}$ (Figure 8e). The excitation spectrum of MS6, monitored within the $\mathrm{Tb}^{3+5} \mathrm{D}_{4} \rightarrow{ }^{7} \mathrm{~F}_{5}$ transition, exhibits a large band (maxima at ca. 260 and $300 \mathrm{~nm}$ ) assigned to BDC ligand and a series of lines assigned to the transition from the ground stats ${ }^{7} \mathrm{~F}_{6}$ to the excited stats ${ }^{5} \mathrm{D}_{2},{ }^{5} \mathrm{G}_{6-4}$, and ${ }^{5} \mathrm{~L}_{10}$ [76] (Figure 8c). Its emission spectrum upon excitation at $260 \mathrm{~nm}$ exhibits the characteristic emission peaks for $\mathrm{Tb}^{3+}$ cation centered at 490, 545, $585,620,650,668$, and $681 \mathrm{~nm}$, which result from deactivation of the ${ }^{5} \mathrm{D}_{4}$ excited state down to the ${ }^{7} \mathrm{~F}_{6-0}$ ground state multipelts (Figure $8 \mathrm{~d}$ ). The most striking green luminescence centered at $545 \mathrm{~nm}$ corresponds to the hypersensitive transition ${ }^{5} \mathrm{D}_{4} \rightarrow{ }^{7} \mathrm{~F}_{5}$ with a lifetime $\tau=1.37 \pm 0.01 \mathrm{~ms}$ (Figure 8f). Furthermore, in both MS5 and MS6 excitation spectra, the low intensity of the intra ${ }^{4} \mathrm{f}_{6}$ and ${ }^{4} \mathrm{f}_{8}$ peaks with respect to the strong bands at wavelengths smaller than $350 \mathrm{~nm}$ point out that the $\mathrm{Eu}^{3+} \mathrm{and}^{\mathrm{T} b^{3+}}$ cation sensitization, via charge transfer from the BDC ligand, is more efficient when compared to direct 4f excitations.
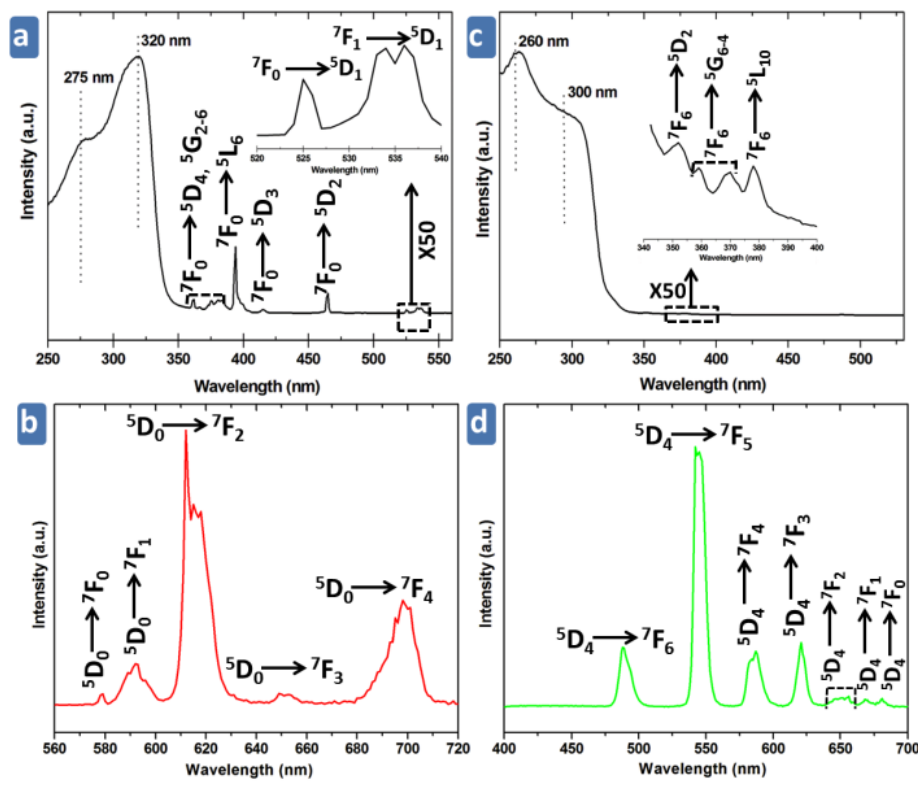

Figure 8. Cont. 

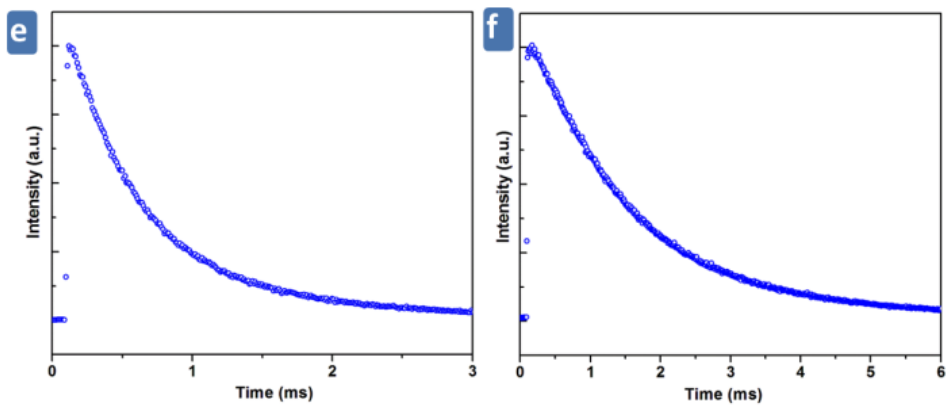

Figure 8. Excitation spectra for MS5 (a) and MS6 (c) detecting luminescence at 615 and $545 \mathrm{~nm}$, respectively. Emission spectra for MS5 (b) and MS6 (d) upon excitation at 260 and $275 \mathrm{~nm}$. Emission decay curves excited at $260 \mathrm{~nm}$ and monitored at 616 and $545 \mathrm{~nm}$ for MS5 (e) and MS6 (f), respectively.
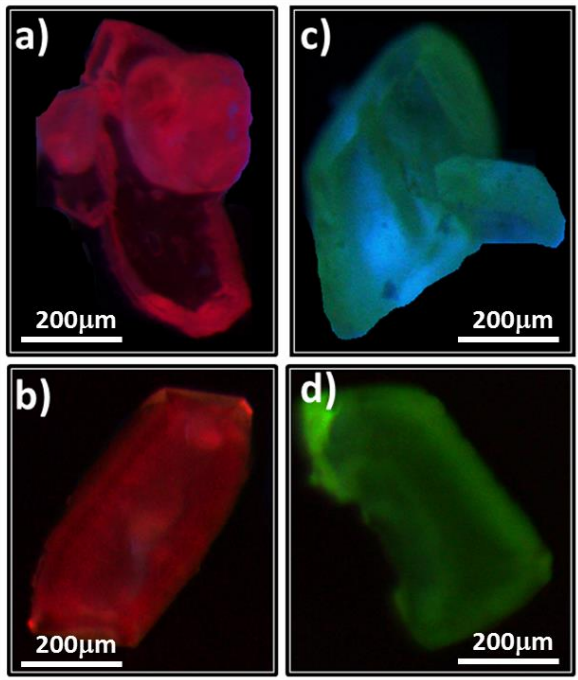

Figure 9. Optical microscopic images under UV light of single crystals of Eu-doped compound MS5 $(\mathbf{a}, \mathbf{b})$ and Tb-doped compound MS6 (c,d).

Moreover, PL properties of MS3 were also studied (Figure S5). The excitation spectrum monitored around $\mathrm{Er}^{3+4} \mathrm{I}_{15 / 2} \rightarrow{ }^{4} \mathrm{~S}_{3 / 2}$ transition exhibits an intense peak at $376 \mathrm{~nm}$, which is attributed to the electronic transition from ${ }^{4} \mathrm{I}_{15 / 2}$ ground state to the excited state ${ }^{3} \mathrm{G}_{11 / 2}$. Its emission spectrum upon excitation at $370 \mathrm{~nm}$ shows the characteristic emission peaks of $\mathrm{Er}^{3+}$ located at 414, 437,492, 582, and $557 \mathrm{~nm}$ corresponding to transitions from ${ }^{2} \mathrm{G}_{9 / 2},{ }^{2} \mathrm{~F}_{9,5,7 / 2},{ }^{2} \mathrm{H}_{9,11 / 2}$, and ${ }^{4} \mathrm{~S}_{3 / 2}$ down to ${ }^{4} \mathrm{I}_{15 / 2}[14,77]$.

\section{Conclusions}

In summary, we have synthesized and characterized novel MOFs assembled from $\mathrm{Li}^{+}, \mathrm{Ln}^{3+}$, and rigid dicarboxylate ligands, formulated as $\left[\mathrm{LiLn}(\mathrm{BDC})_{2}\left(\mathrm{H}_{2} \mathrm{O}\right) \cdot 2\left(\mathrm{H}_{2} \mathrm{O}\right)\right](\mathrm{MS} 1-4)($ where $\mathrm{Ln}=\mathrm{Dy}$, $\mathrm{Ho}, \mathrm{Er}$, and $\mathrm{Yb}$ ) and $\left[\mathrm{LiTb}(\mathrm{BDC})_{2}\right](\mathbf{M S} 7 \mathbf{b})$. Their structures were determined by single $\mathrm{X}$-ray diffraction are based on unusual four-membered rings $\left\{\mathrm{Li}_{2} \mathrm{Ln}_{2} \mathrm{O}_{18}\right\}$ and double inorganic chains constructed from $\left\{\mathrm{LiTbO}_{10}\right\}$ dimeric units, and both exhibit a 3D framework with $1 \mathrm{D}$ trigonal channels running along the $a$ and $c$ axes, containing guest water molecules and anhydrous, respectively. Photoluminescence properties of MS5 and MS6 have been studied showing strong red and green light emissions, attributed to the effective $\mathrm{Eu}^{3+}$ and $\mathrm{Tb}^{3+}$ sensitization via ligands, with a lifetime of $0.84 \pm 0.01 \mathrm{~ms}$ and $1.37 \pm 0.01 \mathrm{~ms}$, respectively. 
Supplementary Materials: The following are available online at www.mdpi.com/2073-4360/8/3/86/s1, Figure S1: SEM images of MS3(a,b); MS7 (c); MS7a (d) and MS7b (e); Figure S2: SEM images and EDX spectra of MS5 (a,c) and MS6 (b,d); Figure S3: Perspective view of the asymmetric unit of MS3(a) and MS7b (b); Figure S4: TGA/DTG curves of MS1, MS2, MS5 and MS6; Figure S5: The emission spectrum of MS3 upon excitation at $370 \mathrm{~nm}$. The inset shows the excitation spectrum detecting luminescence at $557 \mathrm{~nm}$. Table S1: The results of EDX quantitative analysis (in atomic \%) for MS5 and MS6; Table S2: Selected bond lengths (BL/ A) and bond angles $\left(\mathrm{BA} /{ }^{\circ}\right)$ for MS1-4 and MS7b; Table S3: Hydrogen-bond geometry $\left(\AA{ }^{\circ}{ }^{\circ}\right)$ for MS3.

Acknowledgments: Financial support from Spanish Ministerio de Economía y Competitividad (MINECO-13-MAT2013-40950-R, and FPI grant BES-2011-046948 to MSM.A.) and Gobierno del Principado de Asturias (GRUPIN14-060), and El Fondo Europeo de Desarrollo Regional (FEDER) are acknowledged.

Author Contributions: Mohammed S. M. Abdelbaky performed the experiments; Mohammed S. M. Abdelbaky and Zakariae Amghouz designed the experiments, analyzed the data and wrote the manuscript; Santiago García-Granda and Zakariae Amghouz supervised the research work; Santiago García-Granda and José R. García reviewed the manuscript. All authors were involved in reading and approving the final manuscript.

Conflicts of Interest: The authors declare no conflict of interest.

\section{References}

1. Xue, D.X.; Belmabkhout, Y.; Shekhah, O.; Jiang, H.; Adil, K.; Cairns, A.J.; Eddaoudi, M. Tunable Rare Earth fcu-MOF Platform: Access to Adsorption Kinetics Driven Gas/Vapor Separations via Pore Size Contraction. J. Am. Chem. Soc. 2015, 137, 5034-5040. [CrossRef] [PubMed]

2. Alezi, D.; Peedikakkal, A.P.; Weseliński, Ł.J.; Guillerm, V.; Belmabkhout, Y.; Cairns, A.J.; Chen, Z.; Wojtas, Ł.; Eddaoudi, M. Quest for highly connected metal-organic framework platforms: Rare-Earth polynuclear clusters versatility meets net topology needs. J. Am. Chem. Soc. 2015, 137, 5421-5430. [CrossRef] [PubMed]

3. Kim, H.K.; Yun, W.S.; Kim, M.-B.; Kim, J.Y.; Bae, Y.-S.; Lee, J.; Jeong, N.C. A Chemical route to activation of open metal sites in the copper-based metal-organic framework materials HKUST-1 and Cu-MOF-2. J. Am. Chem. Soc. 2015, 137, 10009-10015. [CrossRef] [PubMed]

4. Ma, D.-Y.; Li, Z.; Xiao, J.-X.; Deng, R.; Lin, P.-F.; Chen, R.-Q.; Liang, Y.-Q.; Guo, H.-F.; Liu, B.; Liu, J.-Q. Hydrostable and nitryl/methyl-functionalized metal-organic framework for drug delivery and highly selective $\mathrm{CO}_{2}$ adsorption. Inorg. Chem. 2015, 54, 6719-6726. [CrossRef] [PubMed]

5. Howarth, A.J.; Katz, M.J.; Wang, T.C.; Platero-Prats, A.E.; Chapman, K.W.; Hupp, J.T.; Farha, O.K. High Efficiency Adsorption and removal of selenate and selenite from water using metal-organic frameworks. J. Am. Chem. Soc. 2015, 137, 7488-7494. [CrossRef] [PubMed]

6. Van de Voorde, B.; Bueken, B.; Denayer, J.; de Vos, D. Adsorptive separation on metal-organic frameworks in the liquid phase. Chem. Soc. Rev. 2014, 43, 5766-5788. [CrossRef] [PubMed]

7. Horcajada, P.; Gref, R.; Baati, T.; Allan, P.K.; Maurin, G.; Couvreur, P.; Férey, G.; Morris, R.E.; Serre, C. Metal organic frameworks in biomedicine. Chem. Rev. 2012, 112, 1232-1268. [CrossRef] [PubMed]

8. Lammert, M.; Wharmby, M.T.; Smolders, S.; Bueken, B.; Lieb, A.; Lomachenko, K.A.; de Vos, D.; Stock, N. Cerium-based metal organic frameworks with UiO-66 architecture: Synthesis, properties and redox catalytic activity. Chem. Commun. 2015, 51, 12578-12581. [CrossRef] [PubMed]

9. Valvekens, P.; Vandichel, M.; Waroquier, M.; Van Speybroeck, V.; de Vos, D. Metal-dioxidoterephthalate MOFs of the MOF-74 type: Microporous basic catalysts with well-defined active sites. J. Catal. 2014, 317, 1-10. [CrossRef]

10. Vermoortele, F.; Bueken, B.; Le Bars, G.; van de Voorde, B.; Vandichel, M.; Houthoofd, K.; Vimont, A.; Daturi, M.; Waroquier, M.; Van Speybroeck, V.; et al. Synthesis Modulation as a Tool To Increase the catalytic activity of metal-organic frameworks: The unique case of UiO-66(Zr). J. Am. Chem. Soc. 2013, 135, 11465-11468. [CrossRef] [PubMed]

11. Roy, S.; Chakraborty, A.; Maji, T.K. Lanthanide-organic frameworks for gas storage and as magneto-luminescent materials. Coord. Chem. Rev. 2014, 273-274, 139-164. [CrossRef]

12. Abdelbaky, M.S.M.; Amghouz, Z.; García-Granda, S.; García, J.R. A metal-organic framework assembled from $\mathrm{Y}(\mathrm{III}), \mathrm{Li}(\mathrm{I})$, and terephthalate: Hydrothermal synthesis, crystal structure, thermal decomposition and topological studies. Dalton Trans. 2014, 43, 5739-5746. [CrossRef] [PubMed]

13. Abdelbaky, M.S.M.; Amghouz, Z.; Fernández-Zapico, E.; García-Granda, S.; García, J.R. Metal-organic Frameworks assembled from lanthanide and 2,5-pyridinedicaboxylate with cubane-like $\left[\mathrm{Ln}_{4}(\mathrm{OH})_{4}\right]$ building Units. J. Solid State Chem. 2015, 229, 197-207. [CrossRef] 
14. Amghouz, Z.; García-Granda, S.; García, J.R.; Ferreira, R.A. S.; Mafra, L.; Carlos, L.D.; Rocha, J. Series of metal organic frameworks assembled from $\mathrm{Ln}(\mathrm{III}), \mathrm{Na}(\mathrm{I})$, and Chiral flexible-achiral rigid dicarboxylates exhibiting tunable UV-vis-IR light emission. Inorg. Chem. 2012, 51, 1703-1716. [CrossRef] [PubMed]

15. Bag, P.P.; Wang, X.-S.; Cao, R. Microwave-assisted large scale synthesis of lanthanide metal-organic frameworks (Ln-MOFs), having a preferred conformation and photoluminescence properties. Dalton Trans. 2015, 44, 11954-11962. [CrossRef] [PubMed]

16. Cui, Y.; Yue, Y.; Qian, G.; Chen, B. Luminescent functional metal-organic frameworks. Chem. Rev. 2012, 112, 1126-1162. [CrossRef] [PubMed]

17. Kido, J. Organo lanthanide metal complexes for electroluminescent materials. Chem. Rev. 2002, 102, 2357-2368. [CrossRef] [PubMed]

18. Min, Z.; Singh-Wilmot, M.A.; Cahill, C.L.; Andrews, M.; Taylor, R. Isoreticular lanthanide metal-organic frameworks: Syntheses, structures and photoluminescence of a family of 3D phenylcarboxylates. Eur. J. Inorg. Chem. 2012, 2012, 4419-4426. [CrossRef]

19. Liu, Y.; Zhang, Y.; Hu, G.H.; Zhou, S.; Fan, R.; Yang, Y.; Xu, Y. A Series of lanthanide metal-organic frameworks with interesting adjustable photoluminescence constructed by helical chains. Chem. Eur. J. 2015, 21, 10391-10399. [CrossRef] [PubMed]

20. Decadt, R.; Hecke, K.V.; Depla, D.; Leus, K.; Weinberger, D.; Driessche, I.V.; van der Voort, P.; Deun, R.V. Synthesis, crystal structures, and luminescence properties of carboxylate based rare-earth coordination polymers. Inorg. Chem. 2012, 51, 11623-11634. [CrossRef] [PubMed]

21. Rao, X.; Song, T.; Gao, J.; Cui, Y.; Yang, Y.; Wu, C.; Chen, B.; Qian, G. A highly sensitive mixed lanthanide metal-organic framework self-calibrated luminescent thermometer. J. Am. Chem. Soc. 2013, 135, 15559-15564. [CrossRef] [PubMed]

22. Lee, W.R.; Ryu, D.W.; Lee, J.W.; Yoon, J.H.; Koh, E.K.; Hong, C.S. Microporous lanthanide-organic frameworks with open metal sites: Unexpected sorption propensity and multifunctional properties. Inorg. Chem. 2010, 49, 4723-4725. [CrossRef] [PubMed]

23. Yang, J.; Song, S.Y.; Ma, J.F.; Liu, Y.Y.; Yu, Z.T. Syntheses, structures, photoluminescence, and gas adsorption of rare earth-organic frameworks based on a flexible tricarboxylate. Cryst. Growth Des. 2011, 11, 5469-5474. [CrossRef]

24. Biswas, S.; Jena, H.S.; Goswami, S.; Sanda, S.; Konar, S. Synthesis and characterization of two lanthanide $\left(\mathrm{Gd}^{3+}\right.$ and $\left.\mathrm{Dy}^{3+}\right)$-based three-dimensional metal organic frameworks with squashed metallomacrocycle type building blocks and their magnetic, sorption, and fluorescence properties study. Cryst. Growth Des. 2014, 14, 1287-1295. [CrossRef]

25. Nayak, S.; Nayek, H.P.; Pietzonka, C.; Novitchi, G.; Dehnen, S. A series of three-dimensional lanthanide MOFs: Observation of reversible structural changes controlled by solvent desorption-adsorption, and magnetic properties. J. Mol. Struct. 2011, 1004, 82-87. [CrossRef]

26. Silva, P.; Cunha-Silva, L.; Silva, N.J. O.; Rocha, J.; Almeida Paz, F.A. Metal-organic frameworks assembled from erbium tetramers and 2,5-pyridinedicarboxylic acid. Cryst. Growth Des. 2013, 13, 2607-2617. [CrossRef]

27. Shi, P.-F.; Chen, Z.; Xiong, G.; Shen, B.; Sun, J.-Z.; Cheng, P.; Zhao, B. Structures, luminescence, and magnetic properties of several three-dimensional lanthanide-organic frameworks comprising 4-carboxyphenoxy acetic acid. Cryst. Growth Des. 2012, 12, 5203-5210. [CrossRef]

28. Feng, X.; Zhao, J.; Liu, B.; Wang, L.; Ng, S.; Zhang, G.; Wang, J.; Shi, X.; Liu, Y. A series of lanthanide-organic frameworks based on 2-propyl-1h-imidazole-4,5-dicarboxylate and oxalate: Syntheses, structures, luminescence, and magnetic properties. Cryst. Growth Des. 2010, 10, 1399-1408. [CrossRef]

29. Chen, Q.; Wang, X.-F.; Hu, H.-M.; Wang, J.; An, R.; Dong, F.-X.; Yang, M.-L.; Xue, G.-L. Effect of pH on the construction of lead coordination polymers by the diverse coordination modes of sulfonate functionalized imidazophenanthroline derivative ligand. Polyhedron 2014, 81, 517-524. [CrossRef]

30. Ma, L.-F.; Wang, L.-Y.; Lu, D.-H.; Batten, S.R.; Wang, J.-G. Structural variation from 1D to 3D: Effects of temperature and $\mathrm{pH}$ Value on the construction of $\mathrm{Co}(\mathrm{II})-\mathrm{H}_{2}$ tbip/bpp mixed ligands system. Cryst. Growth Des. 2009, 9, 1741-1749. [CrossRef]

31. Gu, J.; Gao, Z.; Tang, Y. pH and Auxiliary ligand influence on the structural variations of 5(2'-carboxylphenyl) nicotate coordination polymers. Cryst. Growth Des. 2012, 12, 3312-3323. [CrossRef] 
32. Santra, A.; Bharadwaj, P.K. Solvent-induced structural diversity of partially fluorinated, stable $\mathrm{Pb}(\mathrm{II})$ metal-organic frameworks and their luminescence properties. Cryst. Growth Des. 2014, 14, 1476-1485. [CrossRef]

33. Lu, W.; Wei, Z.; Gu, Z.-Y.; Liu, T.-F.; Park, J.; Park, J.; Tian, J.; Zhang, M.; Zhang, Q.; Gentle, T.; et al. Tuning the structure and function of metal-organic frameworks via linker design. Chem. Soc. Rev. 2014, 43, 5561-5593. [CrossRef] [PubMed]

34. Yaghi, O.M.; O'Keeffe, M.; Ockwig, N.W.; Chae, H.K.; Eddaoudi, M.; Kim, J. Reticular synthesis and the design of new materials. Nature 2003, 423, 705-714. [CrossRef] [PubMed]

35. Chae, H.K.; Siberio-Perez, D.Y.; Kim, J.; Go, Y.; Eddaoudi, M.; Matzger, A.J.; O'Keeffe, M.; Yaghi, O.M. A route to high surface area, porosity and inclusion of large molecules in crystals. Nature 2004, 427, 523-527. [CrossRef] [PubMed]

36. Thuery, P.; Masci, B. Two- and Three-dimensional assemblies formed by alkali metal $\left(\mathrm{Li}^{+}-\mathrm{Cs}^{+}\right)$and $\mathrm{Ba}^{2+}$ ions with Bicyclo[2.2.2]oct-7-ene-2,3,5,6-tetracarboxylic acid. Cryst. Growth Des. 2010, 10, 4109-4117. [CrossRef]

37. Horike, S.; Matsuda, R.; Tanaka, D.; Mizuno, M.; Endo, K.; Kitagawa, S. Immobilization of sodium ions on the pore surface of a porous coordination polymer. J. Am. Chem. Soc. 2006, 128, 4222-4223. [CrossRef] [PubMed]

38. Hou, L.; Zhang, J.-P.; Chen, X.-M.; Ng, S.W. Two highly-connected, chiral, porous coordination polymers featuring novel heptanuclear metal carboxylate clusters. Chem. Commun. 2008, 34, 4019-4021. [CrossRef] [PubMed]

39. Tominaka, S.; Yeung, H.H.-M.; Henke, S.; Cheetham, A.K. Coordination environments and $\pi$-conjugation in dense lithium coordination polymers. CrystEngComm 2016, 18, 398-406. [CrossRef]

40. Gou, L.; Zhang, H.-X.; Fan, X.-Y.; Li, D.-L. Lithium based coordination polymer as anode for Li-ion battery. Inorg. Chim. Acta. 2013, 394, 10-14. [CrossRef]

41. Liu, Y.-Y.; Zhang, J.; Xu, F.; Sun, L.-X.; Zhang, T.; You, W.-S.; Zhao, Y.; Zeng, J.; Cao, Z.; Yang, D. Lithium-based 3D coordination polymer with hydrophilic structure for sensing of solvent molecules. Cryst. Growth Des. 2008, 8, 3127-3129. [CrossRef]

42. Banerjee, D.; Kim, S.J.; Parise, J.B. Lithium based metal-organic framework with exceptional stability. Cryst. Growth Des. 2009, 9, 2500-2503. [CrossRef]

43. Banerjee, D.; Borkowski, L.A.; Kim, S.J.; Parise, J.B. Synthesis and Structural characterization of lithium-based metal-organic frameworks. Cryst. Growth Des. 2009, 9, 4922-4926. [CrossRef]

44. Banerjee, D.; Parise, J.B. Recent advances in s-block metal carboxylate networks. Cryst. Growth Des. 2011, 11, 4704-4720. [CrossRef]

45. Peng, G.; Ma, L.; Cai, J.; Liang, L.; Deng, H.; Kostakis, G.E. Influence of alkali metal cation (Li(I), Na(I), K(I)) on the construction of chiral and achiral heterometallic coordination polymers. Cryst. Growth Des. 2011, 11, 2485-2492. [CrossRef]

46. Frigoli, M.; El Osta, R.; Marrot, J.; Medina, M.E.; Walton, R.I.; Millange, F. Heterobimetallic sodium-lithium based metal-organic framework showing the $\beta$-cristobalite topology and having high permanent porosity. Eur. J. Inorg. Chem. 2013, 2013, 1138-1141. [CrossRef]

47. Mendoza-Cortes, J.L.; Han, S.S.; Goddard, W.A. High $\mathrm{H}_{2}$ uptake in Li-, Na-, K-metalated covalent organic frameworks and metal organic frameworks at 298 K. J. Phys. Chem. A 2012, 116, 1621-1631. [CrossRef] [PubMed]

48. Han, S.S.; Goddard, W.A. Lithium-Doped Metal-organic frameworks for reversible $\mathrm{H}_{2}$ storage at ambient temperature. J. Am. Chem. Soc. 2007, 129, 8422-8423. [CrossRef] [PubMed]

49. Mulfort, K.L.; Hupp, J.T. Alkali metal cation effects on hydrogen uptake and binding in metal-organic frameworks. Inorg. Chem. 2008, 47, 7936-7938. [CrossRef] [PubMed]

50. Blomqvist, A.; Araujo, C.M.; Srepusharawoot, P.; Ahuja, R. Li-decorated metal-organic framework 5: A route to achieving a suitable hydrogen storage medium. Proc. Natl. Acad. Sci. USA 2007, 104, 20173-20176. [CrossRef] [PubMed]

51. Dalach, P.; Frost, H.; Snurr, R.Q.; Ellis, D.E. Enhanced hydrogen uptake and the electronic structure of lithium-doped metal-organic frameworks. J. Phys. Chem. C 2008, 112, 9278-9284. [CrossRef]

52. Mavrandonakis, A.; Tylianakis, E.; Stubos, A.K.; Froudakis, G.E. Why Li doping in MOFs enhances $\mathrm{H}_{2}$ storage capacity? A multi-scale theoretical study. J. Phys. Chem. C 2008, 112, 7290-7294. [CrossRef] 
53. Klontzas, E.; Mavrandonakis, A.; Tylianakis, E.; Froudakis, G.E. Improving hydrogen storage capacity of MOF by functionalization of the organic linker with lithium atoms. Nano Lett. 2008, 8, 1572-1576. [CrossRef] [PubMed]

54. Kolmann, S.J.; Chan, B.; Jordan, M.J.T. Modelling the interaction of molecular hydrogen with lithium-doped hydrogen storage materials. Chem. Phys. Lett. 2008, 467, 126-130. [CrossRef]

55. Wang, Lu.; Han, Y.; Feng, X.; Zhou, J.; Qi, P.; Wang, B. Metal-organic frameworks for energy storage: Batteries and supercapacitors. Coord. Chem. Rev. 2016, 307, 361-381. [CrossRef]

56. Zou, F.; Chen, Y.-M.; Liu, K.; Yu, Z.; Liang, W.; Bhaway, S.M.; Gao, M.; Yu, Z. Metal organic frameworks

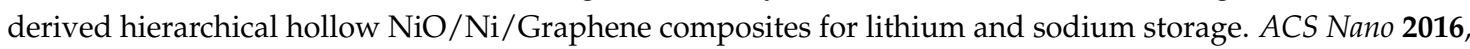
10, 377-386. [CrossRef] [PubMed]

57. Kong, S.; Dai, R.; Li, H.; Sun, W.; Wang, Y. Microwave hydrothermal synthesis of Ni-based metal-organic frameworks and their derived yolk-shell $\mathrm{NiO}$ for Li-ion storage and supported ammonia borane for hydrogen desorption. ACS Sustain. Chem. Eng. 2015, 3, 1830-1838. [CrossRef]

58. Schmidt, S.; Sheptyakov, D.; Jumas, J.-C.; Medarde, M.; Benedek, P.; Novák, P.; Sallard, S.; Villevieille, C. Lithium iron methylenediphosphonate: A model material for neworganic-inorganic hybrid positive electrode materials for Li ion batteries. Chem. Mater. 2015, 27, 7889-7895. [CrossRef]

59. Amghouz, Z.; Roces, L.; García-Granda, S.; García, J.R.; Souhail, B.; Mafra, L.; Shi, F.-N.; Rocha, J. Metal organic frameworks assembled from $\mathrm{Y}(\mathrm{III}), \mathrm{Na}(\mathrm{I})$, and chiral flexible-achiral rigid dicarboxylates. Inorg. Chem. 2010, 49, 7917-7926. [CrossRef] [PubMed]

60. Han, Y.; Li, X.; Li, L.; Ma, C.; Shen, Z.; Song, Y.; You, X. Structures and properties of porous coordination polymers based on lanthanide carboxylate building units. Inorg. Chem. 2010, 49, 10781-10787. [CrossRef] [PubMed]

61. Black, C.A.; Costa, J.S.; Fu, W.T.; Massera, C.; Roubeau, O.; Teat, S.J.; Aromı, G.; Gamez, P.; Reedijk, J. 3-D lanthanide metal-organic frameworks: Structure, photoluminescence, and magnetism. Inorg. Chem. 2009, 48, 1062-1068. [CrossRef] [PubMed]

62. Liu, Y.-Y.; Zhang, J.; Sun, L.-X.; Xu, F.; You, W.-S.; Zhao, Y. Solvothermal synthesis and characterization of a lithium coordination polymer possessing a highly stable 3D network structure. Inorg. Chem. Commun. 2008, 11, 396-399. [CrossRef]

63. Stein, I.; Ruschewitz, U. Poly[di-[mu]3-aqua-[mu]4-terephthalato-dirubidium]. Acta Crystallogr. Sect. E 2006, E62, m2116-m2118. [CrossRef]

64. Stein, I.; Ruschewitz, U. Poly[di-[mu]3-aqua-[mu]4-terephthalato-dicaesium]. Acta Crystallogr. Sect. E 2007, E63, m382-m384. [CrossRef]

65. Dale, S.H.; Elsegood, M.R.J. Poly[sodium(I)-[mu]6-hydrogen benzene-1,4-dicarboxylato]. Acta Crystallogr. Sect. C 2003, E59, m475-m477. [CrossRef]

66. CrysAlis CCD; Version 1.171.32.37; release 24-10-2008 CrysAlis171. NET, compiled Oct 24, 2008, 09:44:38; Oxford Diffraction Ltd.: Abingdon, UK, 2008.

67. CrysAlis RED; Version 1.171.32.37; release 24-10-2008 CrysAlis171. NET, compiled Oct 24, 2008, 09:44:38; Oxford Diffraction Ltd.: Abingdon, UK, 2008.

68. Sheldrick, G.M. SHELXL-97, Program for Refinement of Crystal Structures; University of Gottingen: Gottingen, Germany, 1997.

69. Parkin, S.; Moezzi, B.; Hope, H. XABS2: An empirical absorption correction program. J. Appl. Crystallogr. 1995, 28, 53-56. [CrossRef]

70. Spek, A.L. PLATON, an integrated tool for the analysis of the results of a single crystal structure determination. Acta Crystallogr. Sect. A Fundam. Crystallogr. 1990, 46, C34.

71. Spek, A.L. PLATON, a multipurpose crystallographic tool; Utrecht University: Utrecht, Netherlands, 1998.

72. Brandenburg, K. DIAMOND; Version 3.1; Crystal Impact GbR: Bonn, Germany, 2007.

73. Blatov, V.A. Multipurpose crystallochemical analysis with the program package TOPOS. Available online: http:/ / www.topos.ssu.samara.ru (accessed on 20 January 2016).

74. Blatov, V.A. Nanocluster analysis of intermetallic structures with the program package TOPOS. Struct. Chem. 2012, 23, 955-963. [CrossRef]

75. Dieke, G.H. Spectra and Energy Levels of Rare Earth Ionsin Crystals; Wiley Interscience: New York, NY, USA, 1968. 
76. Debasu, M.L.; Ananias, D.; Rocha, J.; Malta, O.L.; Carlos, L.D. Energy-transfer from Gd(III) to Tb(III) in (Gd, Yb,Tb) $\mathrm{PO}_{4}$ nanocrystals. Phys. Chem. Chem. Phys. 2013, 15, 15565-15571. [CrossRef] [PubMed]

77. Li, H.; Zhu, G.; Ren, H.; Li, Y.; Hewitt, I.J.; Qiu, S. The synthesis of multiwalled rare-earth phosphate nanomaterials using organophosphates with upconversion properties. Eur. J. Inorg. Chem. 2008, 2008, 2033-2037. [CrossRef] 